OPEN ACCESS

Edited by:

Olivier Lamotte,

UMR Agroécologie, Dijon, France

Reviewed by:

Guus Bakkeren,

Agriculture and Agri-Food Canada,

Canada

Manuel Acosta,

Universidad de Murcia, Spain

*Correspondence:

Guohuai L

liguohuai@mail.hzau.edu.cn

Specialty section:

This article was submitted to

Plant Physiology,

a section of the journal

Frontiers in Physiology

Received: 01 February 2016

Accepted: 25 April 2016

Published: 09 May 2016

Citation:

Gao L, Wang Y, Li Z, Zhang H, Ye J and Li G (2016) Gene Expression Changes during the Gummosis Development of Peach Shoots in

Response to Lasiodiplodia theobromae Infection Using RNA-Seq.

Front. Physiol. 7:170.

doi: 10.3389/fphys.2016.00170

\section{Gene Expression Changes during the Gummosis Development of Peach Shoots in Response to Lasiodiplodia theobromae Infection Using RNA-Seq}

\author{
Lei Gao ${ }^{1}$, Yuting Wang ${ }^{1}$, Zhi $\mathrm{Li}^{2}$, He Zhang ${ }^{1}$, Junli Ye ${ }^{1}$ and Guohuai $\mathrm{Li}^{1 *}$ \\ ${ }^{1}$ Key Laboratory of Horticultural Plant Biology, Ministry of Education, Huazhong Agricultural University, Wuhan, China, ${ }^{2}$ State \\ Key Laboratory of Crop Stress Biology in Arid Areas, College of Horticulture, Northwest Agriculture and Forestry University, \\ Yangling, China
}

Lasiodiplodia theobromae is a causal agent of peach (Prunus persica L.) tree gummosis, a serious disease affecting peach cultivation and production. However, the molecular mechanism underlying the pathogenesis remains unclear. RNA-Seq was performed to investigate gene expression in peach shoots inoculated or mock-inoculated with L. theobromae. A total of 20772 genes were detected in eight samples; 4231, 3750, 3453, and 3612 differentially expressed genes were identified at 12, 24, 48, and $60 \mathrm{~h}$ after inoculation, respectively. Furthermore, 920 differentially co-expressed genes (515 upregulated and 405 downregulated) were found, respectively. Gene ontology annotation revealed that phenylpropanoid biosynthesis and metabolism, uridine diphosphate-glucosyltransferase activity, and photosynthesis were the most differentially regulated processes during gummosis development. Significant differences were also found in the expression of genes involved in glycometabolism and in ethylene and jasmonic acid biosynthesis and signaling. These data illustrate the dynamic changes in gene expression in the inoculated peach shoots at the transcriptome level. Overall, gene expression in defense response and glycometabolism might result in the gummosis of peach trees induced by $L$. theobromae.

Keywords: gummosis, Prunus, L. theobromae, RNA-Seq, defense response, glycometabolism

\section{INTRODUCTION}

Fungal gummosis of peach (Prunus persica L.) trees was first reported in 1974 in Central Georgia (Weaver, 1974). Three species of Botryosphaeria fungus cause this disease, namely, Lasiodiplodia theobromae, Diplodia seriata, and Fusicoccum aesculi were identified and reported in followup studies (Britton and Hendrix, 1982; Wang et al., 2011). Previous studies suggested that the pathogenicity of $L$. theobromae JMB-122 was stronger than other species (Wang et al., 2011). The hyphae of $L$. theobromae were observed on the phloem of peach shoots at 2 days post-inoculation (Li et al., 2014b). In cashew gummosis caused by L. theobromae, hyphae were often colonized in the rays, vessels and parenchyma cells (Muniz et al., 2011). Botryosphaeria spp. are capable of degrading lignin and pectin (Alves da Cunha et al., 2003). Degradation of cell walls was observed in peach 
shoots and cashew branches infected by L. theobromae (Muniz et al., 2011; Li et al., 2014b). In addition, L. theobromae induced the expression of cell wall degrading-related genes and triggered cell death of the inoculated peach shoots (Li et al., 2014b). A serious case of peach gummosis can cause tree death, which significantly affects agronomy and economics (Beckman et al., 2003; Wang et al., 2011). The main symptom of peach gummosis is gum exudation from tree trunks, branches, and fruits. The main components of gum are polysaccharides (Simas et al., 2008; Simas-Tosin et al., 2010). A recent study has observed polysaccharide accumulation and investigated carbohydrate metabolism changes in peach shoots infected with L. theobromae ( $\mathrm{Li}$ et al., 2014a). These results suggest that glycometabolism directly relates to peach gum formation.

Pathogen attack in plants alters the levels of various secondary metabolites, among which, phenylpropanoid compounds contribute to pathogen resistance (Dixon et al., 2002). Plant hormones such as ethylene (ET) and jasmonates [mainly jasmonic acid (JA) and methyl jasmonate (JA-ME)] are essential factors in gum formation. Ethephon (ETH, 2chloroethylphosphonic acid, ET-releasing compound) can induce sour cherry gummosis (Olien and Bukovac, 1982), and ET can initiate gum duct formation in almond fruits (Morrison et al., 1987). The application of ET in tulip bulbs leads to gum formation, and the effect can be prevented through pretreatment with the ET receptor inhibitor 1-methylcyclopropane (1-MCP) (de Wild et al., 2002). JA can induce gummosis in tulip (Skrzypek et al., 2005a,b) and grape hyacinth (Miyamoto et al., 2010), as well as in various species of stone-fruit trees such as plum shoots and fruits (Saniewski et al., 2002), apricot (Saniewski et al., 2001), and peach shoots (Saniewski et al., 1998; Li et al., 2015).

High-throughput sequencing technologies have been recently developed for transcriptome profiling, referred to as RNA-Seq (Wang et al., 2009; Marguerat and Bähler, 2010). RNA-Seq has been widely applied to study plant diseases caused by bacteria (Kim et al., 2011; Socquet-Juglard et al., 2013), fungi (Xu et al., 2011; de Jonge et al., 2012; Kunjeti et al., 2012; Windram et al., 2012; Czemmel et al., 2015), and viruses (Zhang et al., 2012; Rubio et al., 2015) because of its capacity to elucidate the molecular mechanism underlying plant-pathogen interactions.

The molecular mechanism underlying peach fungal gummosis remains unclear to date. Thus, we used high-throughput Illumina sequencing in the present study to analyze the transcriptome of peach shoots at 12, 24, 48, and $60 \mathrm{~h}$ after inoculation (HAI) with $L$. theobromae. We analyzed differentially expressed genes (DEGs) and their significantly enriched pathways after pathogen infection, and discussed possible factors influencing gummosis development. The global view of the host transcriptional changes could contribute to our understanding of gum symptom development in peach shoots infected with $L$. theobromae.

\section{MATERIALS AND METHODS}

\section{Plant Material and Pathogen Material}

Peach plants (P. persica L. "Spring Snow") was grafted onto wild peach rootstocks and cultivated in the experiment field of Huazhong Agricultural University (Wuhan, Hubei Province, China). Current-year shoots approximately $6 \mathrm{~mm}$ in diameter were collected from 4-year-old peach plants in 2012. L. theobromae strain JMB-122 was isolated from Hubei Province, China (Wang et al., 2011). Before inoculation, L. theobromae JMB-122 was cultured on potato dextrose agar (PDA) medium at $28^{\circ} \mathrm{C}$ for 3 days.

\section{Inoculation of Peach Shoots with L. theobromae}

The inoculation method was based on a previous study ( $\mathrm{Li}$ et al., 2014b). In brief, after surface-sterilized peach shoots were cut into $15 \mathrm{~cm}$-long segments and then wounded with a sterilized needle. A single mycelial plug (4 $\mathrm{mm}$ in diameter) of L. theobromae was placed onto the wound point. Shoot segments inoculated with sterile PDA medium without $L$. theobromae were treated as controls. The inoculated and control shoots were placed in glass bottles containing $100 \mathrm{~mL}$ of sterilized water. The shoots and glass bottles were covered with clear plastic wrap and then placed in a light incubator at $28^{\circ} \mathrm{C}, 90 \%$ relative humidity with a photoperiod of 12/12 h light (20,000 lux) /dark.

\section{Measurement of ET Production}

The inoculated and mock-inoculated shoots were used to measure the ET production rate. The mycelial plug or the PDA medium was removed before the shoots were placed in a $500 \mathrm{~mL}$ Erlenmeyer flask. Each Erlenmeyer flask containing about 15 shoots was sealed airtight by a rubber stopper. The shoots were sealed for up to $6 \mathrm{~h}$ at $28^{\circ} \mathrm{C}$ at 0,1 , 2 , 3, and 4 days after inoculation. Then, $1 \mathrm{~mL}$ gas was extracted from the airtight Erlenmeyer flask by using gastight syringes. ET was detected using a gas chromatograph (Agilent, 7890A, USA) equipped with a DB-624 column and a flame ionization detector (FID). The injection, FID, and column temperature was $250^{\circ} \mathrm{C}, 250$ and $40^{\circ} \mathrm{C}$, respectively. The pressure in the column was $2.8109 \mathrm{~Pa}$. The carrier gas was pure nitrogen $\left(\mathrm{N}_{2}\right)$ with a rate of $16 \mathrm{~mL} \cdot \mathrm{min}^{-1}$. The external standard method was used in this study; the retention time of the standard sample (from Newradar special GAS Co., Ltd., China) and the peak area were used as qualitative and quantitative data, respectively. The rate of ET production was expressed as $\mu \mathrm{L} \cdot \mathrm{kg}^{-1} \cdot \mathrm{h}^{-1}$. The results of ET production rate are shown as the means \pm SD of three independent biological replicates.

\section{Plant Sample Preparation and RNA Preparation}

Peach shoot tissues were collected within a $0.5-1.0 \mathrm{~cm}$ range from the wound point of the inoculated shoots $(\mathrm{J})$ and the mockinoculated shoots (C) at 12, 24, 48, and 60 HAI. The samples were immediately frozen in liquid nitrogen and stored at $-80^{\circ} \mathrm{C}$. Both infected and control samples were collected from eight peach shoots in a randomized manner. The $\mathrm{J}$ and $\mathrm{C}$ samples at $12,24,48$, and $60 \mathrm{HAI}$ were used to extract RNA. The total RNA was extracted using the EASYspin Plus RNA kit (Aidlab, Beijing, China). Any genomic DNA was removed by DNAase (TaKaRa, Dalian, China). The RNA yield and purity were checked 
through NANODROP 2000 (Thermo, USA), and RNA integrity was verified through electrophoresis on 1.5\% agarose gel.

\section{cDNA Library Construction and RNA-Seq}

The eight RNA samples were sent for RNA-Seq using the Illumina Genome Analyzer at ABLife (Wuhan, China) in 2012. For each sample, $10 \mu \mathrm{g}$ of total RNA was used for RNA-Seq library preparation. Polyadenylated mRNAs were purified and concentrated with dT-conjugated magnetic beads (Invitrogen) before used for directional RNA-Seq library preparation. The purified mRNAs were iron-fragmented at $95^{\circ} \mathrm{C}$ followed by end repair and $5^{\prime}$ adaptor ligation. Then, reverse transcription was performed with RT primer harboring $3^{\prime}$ adaptor sequence and randomized hexamer. The cDNAs were purified and amplified, and PCR products corresponding to 200-500 bp were purified, quantified, and stored at $-80^{\circ} \mathrm{C}$ until used for sequencing. The libraries for high-throughput sequencing were prepared following the manufacturer's protocol and then applied to the Illumina GAIIx system for 80-nucleotide single-end sequencing. Raw data were collected by the sequencer. Reads containing two $\mathrm{N}$ were removed, the adaptor was trimmed on the basis of adapter information, and low-quality reads were trimmed. After these steps, reads with lengths $\geq 20$ nt were considered clean.

\section{Mapping Reads to the Genome and Identification of Differentially Expressed Genes (DEGs)}

The P. persica v1.0 genome dataset was used as a reference. The abundance of each gene was normalized to reads per kilo bases per million reads (RPKM) for between-sample comparison purposes. The edgeR software was applied to identify DEGs. Fold change $\left(\left|\log _{2} \mathrm{FC}\right| \geq 1\right)$ and $p$-value $(p \leq 0.01)$ were used as statistical significance indexes.

\section{Validation of RNA-Seq Analysis by Quantitative Real-Time Polymerase Chain Reaction (qRT-PCR)}

First-strand cDNA was synthesized from $1.0 \mu \mathrm{g}$ of RNA using oligo (dT) primers by using a PrimeScript ${ }^{\circledR}$ RT Reagent Kit with gDNA Eraser (TaKaRa, Dalian, China) in accordance with the manufacturer's protocol. The cDNA was diluted to a final concentration of $300 \mathrm{ng} \cdot \mu \mathrm{L}^{-1}$ and used as the template for qRT-PCR. qRT-PCR was performed on the LightCyler ${ }^{\circledR} 480$ real-time detection system (Roche Diagnostics, Switzerland). The intercalation dye SYBR Green (TransStart ${ }^{R}$ ) was used as a fluorescent reporter. Translation elongation factor 2 was used as a reference gene to normalize gene expression in according with a previously published report (Sherif et al., 2012). In brief, $15 \mu \mathrm{L}$ of the PCR system contained $300 \mathrm{ng}$ of cDNA, $10 \mathrm{mmol}$ of each primer, and $7.5 \mu \mathrm{L}$ of $2 \times$ TransStart ${ }^{\circledR}$ Top Green qPCR SuperMix (TransGen, Beijing, China). The reaction was performed at $95^{\circ} \mathrm{C}$ for $30 \mathrm{~s}$, followed by 45 cycles of $95^{\circ} \mathrm{C}$ for $5 \mathrm{~s}, 60^{\circ} \mathrm{C}$ for $30 \mathrm{~s}, 72^{\circ} \mathrm{C}$ for $30 \mathrm{~s}$. Relative gene expression was calculated using the comparative $2^{-\Delta \Delta C T}$ method (Livak and Schmittgen, 2001). The qRT-PCR results are shown as the means \pm SD of three independent biological replicates.

\section{RESULTS}

\section{Symptom Changes in Peach Shoots Infected with $L$. theobromae}

A typical symptom observed in the inoculated peach shoots was the increased lesions compared with the mock-inoculated peach shoots. At $12 \mathrm{HAI}$, the lesion diameter was about $5 \mathrm{~mm}$. From 24 HAI to $48 \mathrm{HAI}$, lesions developed at a comparatively rapid speed. The lesions were $17.3 \pm 1.0 \mathrm{~mm}$ at $60 \mathrm{HAI}$ (Figure 1B). Another typical symptom was the distinct red color surrounding the lesions at the beginning of $24 \mathrm{~h}$. Importantly, the gum exudation was visible on the inoculated point at $60 \mathrm{~h}$ (Figure 1A), with a $29.3 \pm 4.7 \mathrm{mg}$ gum weight (Figure 1B) per inoculated shoot in average. When peach shoots were inoculated with $L$. theobromae, the maximum production rate of ET was reached at 1 day, but this rate declined during 2-4 days. ET production in the control plants on days 1-4 fell lower than the minimum detectable concentration. Thus, gas chromatography failed to generate any efficient data.

\section{Analyses of RNA-Seq Data}

In total, eight cDNA preparations were sequenced. The number of raw reads produced for each library exceeded 10 million (Table 1). After filtering, most of the clean reads were still more than $80 \%$ of the raw data, except C12 $(66.15 \%)$ and C24 (79.24\%). The useful length of the vast majority of the sequence was $66-67 \mathrm{bp}$, indicating few number of low-quality bases. The trimmed RNA-Seq reads were mapped on the v1.0 P. persica reference genome. Approximately $72-81 \%$ of the clean reads were mapped to the genome, except C12 (59.20\%). The unique mapped reads accounted for more than $94 \%$ of the total mapped reads, indicating the low proportion of rRNA contamination. The clean reads were distributed mainly (an average of $75.1 \%$ ) in the coding sequence of the genomic regions (Supplementary Table 1). A total of 20771 genes were detected as being expressed using the eight samples, or $74.58 \%$ of the total 27852 predicted genes of the v1.0 peach genome (Verde et al., 2013). In general, the RPKM value of the $60-70 \%$ reads of each sample was below 20 , indicating a greater proportion of lowly expressed genes than highly expressed genes.

\section{DEGs in $\mathrm{J}$ and $\mathrm{C}$}

The selection standards for DEGs are the fold change $\geq 2$ or $\leq-2$ and $p \leq 0.01$ (Supplementary Figure 1). Of the 20771 genes detected in this transcriptome, 4231, 3750, 3453, and 3612 were differentially expressed at $p \leq 0.01$ and $\left|\log _{2} \mathrm{FC}\right| \geq 1$ between $\mathrm{J} 12$ and $\mathrm{C} 12, \mathrm{~J} 24$ and $\mathrm{C} 24, \mathrm{~J} 48$ and $\mathrm{C} 48$, and $\mathrm{J} 60$ and $\mathrm{C} 60$, respectively. Then, 515 and 405 DEGs were co-upregulated and co-downregulated among the four comparisons, respectively (Table 2; Supplementary Table 2). The number of upregulated genes was less than that of downregulated genes between J24 and C24, and J60 and C60. The top 10 upregulated and top 10 downregulated genes in each of the four post-inoculated stages are listed in the Supplementary Table 3. A total of 1662, 645, 527, and 964 DEGs were specific for J12 vs. C12, J24 vs. C24, J48 vs. C48, and J60 vs. C60, respectively (Figure 2; Supplementary Table 4). In addition, the number of upregulated genes was 

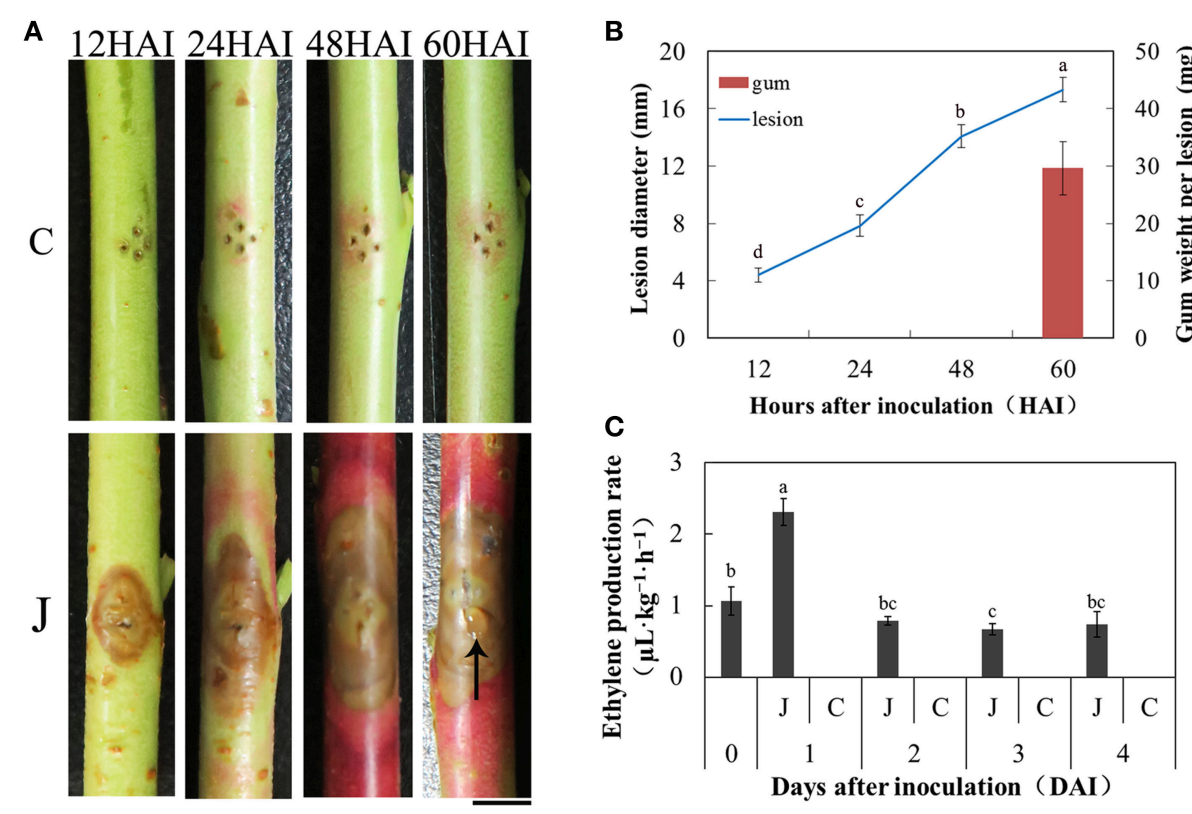

FIGURE 1 | Peach gummosis development and ethylene production rate. (A) Development of symptoms of peach current-year detached shoots inoculated with L. theobromae. C, mock-inoculated peach shoots; J, inoculated peach shoots; HAl, hours after inoculation; The black arrow indicates gum exudation; Bar is 5 mm. (B) Dynamic changes in lesion diameter at different hours and gum weight per lesion at $60 \mathrm{HAl}$. The values presented are the means \pm SD of six independent determinations. (C) ET production rate of the inoculated and mock-inoculated current-year peach shoots. At 0 days, the shoots were only wounded. In the days following, no ET was detectable in control shoots. Data were analyzed by ANOVA using SAS program package (version 8.1; SAS Institute, Cary, NC) to determine differences in lesion diameter (B) and ET production rate $\mathbf{( C )}$. Means with the same letters are not significantly different at the $5 \%$ level by Duncan's multiple range test.

TABLE 1 | Summary of RNA-Seq data collected from the inoculated (J) and the mock-inoculated (C) peach shoots at the four selected hours after inoculation (HAI) and assemblies.

\begin{tabular}{|c|c|c|c|c|c|}
\hline \multicolumn{2}{|c|}{ Sample } & \multirow{2}{*}{$\begin{array}{c}\text { Raw reads } \\
10620646\end{array}$} & \multirow{2}{*}{$\begin{array}{c}\text { Clean reads } \\
8763947(82.52 \%)\end{array}$} & \multirow{2}{*}{$\begin{array}{c}\text { Reads mapped } \boldsymbol{P} \text { persica v } \mathbf{1 . 0} \\
6320708(72.12 \%)\end{array}$} & \multirow{2}{*}{$\begin{array}{l}\text { Unique mapped } \\
6012821(95.13 \%)\end{array}$} \\
\hline $12 \mathrm{HAl}$ & $J$ & & & & \\
\hline & $\mathrm{C}$ & 14403060 & 9527620 (66.15\%) & $5640474(59.20 \%)$ & 5360326 (95.03\%) \\
\hline \multirow[t]{2}{*}{$24 \mathrm{HAl}$} & $J$ & 12457518 & 10567109 (84.83\%) & 7859332 (74.38\%) & 7501716 (95.45\%) \\
\hline & C & 10672969 & 8456836 (79.24\%) & 6083248 (71.93\%) & 5774232 (94.92\%) \\
\hline \multirow[t]{2}{*}{$48 \mathrm{HAl}$} & $J$ & 13085397 & 11608410 (88.71\%) & 9428886 (81.22\%) & 8998979 (95.44\%) \\
\hline & $\mathrm{C}$ & 12063922 & 9888030 (81.96\%) & 7513771 (75.99\%) & 7140544 (95.03\%) \\
\hline \multirow[t]{2}{*}{$60 \mathrm{HAl}$} & J & 12290504 & 10417691 (84.76\%) & 8248739 (79.18\%) & 7869553 (95.40\%) \\
\hline & $\mathrm{C}$ & 10015740 & 8434545 (84.21\%) & 6604147 (78.30\%) & 6306888 (95.50\%) \\
\hline
\end{tabular}

almost the same as that of the downregulated genes for J12 vs. C12, J24 vs. C24, and J48 vs. C48, respectively. However, in the comparison of J60 vs. C60, 288 (30\%), and 676 (70\%) of the 964 specific DEGs were up- and downregulated, respectively (Table 2).

\section{Functional Analysis of DEGs in $\mathrm{J}$ and $\mathrm{C}$}

The Database for Annotation, Visualization and Integrated Discovery (DAVID) online platform (https://david.ncifcrf.gov/) was used to analyze the function of the DEGs. The upand down-regulated cluster groups of the DEGs were subjected to gene ontology (GO) term analysis. Among the upregulated clusters, the DEGs were significantly enriched in "phenylpropanoid biosynthetic and metabolic process." Glycosyltransferase, especially the relevant uridine diphosphate (UDP)-glucosyltransferase genes were highly enriched from $24 \mathrm{~h}$ in the inoculated shoots. At $12 \mathrm{HAI}$, the genes involved in JA biosynthesis were highly enriched. Among the downregulated clusters of the GO term analysis, chloroplast, plastid, and photosynthesis were significantly enriched (Supplementary Table 5). In the comparison of "J12 vs. C12," the metabolic process of starch, glucan, and polysaccharides was downregulated. Furthermore, the expression levels of relevant DEGs controlling the catabolic process of starch, glucan, and polysaccharide were downregulated in the inoculated shoots (detailed data in Supplementary Table 6). The same tendency was also observed on three other comparisons. 
TABLE 2 | Distribution of differentially expressed genes (DEGs) between the inoculated $(\mathrm{J})$ and control $(\mathrm{C})$ peach shoots at each of the four selected hours after inoculation (HAI).

\begin{tabular}{lccccc}
\hline & J12 vs. C12 & J24 vs. C24 & J48 vs. C48 & J60 vs. C60 & J vs. C \\
\hline Total DEGs & 4231 & 3750 & 3453 & 3612 & 920 \\
Upregulated & 2257 & 1860 & 1768 & 1437 & 515 \\
Downregulated & 1974 & 1980 & 1685 & 2175 & 405 \\
Shared DEGs & 2569 & 3105 & 2926 & 2648 & \\
Specific DEGs & 1662 & 645 & 527 & 964 & \\
Upregulated & 880 & 360 & 248 & 288 & \\
Downregulated & 782 & 285 & 279 & 676 & \\
\hline
\end{tabular}

$\mathrm{J} 12$ vs. $\mathrm{C} 12$ indicates a comparison between $\mathrm{J}$ and $\mathrm{C}$ at $12 \mathrm{HAl}$; J vs. C represents the co-DEGs (co-upregulated and co-downregulated) among the four comparisons performed.

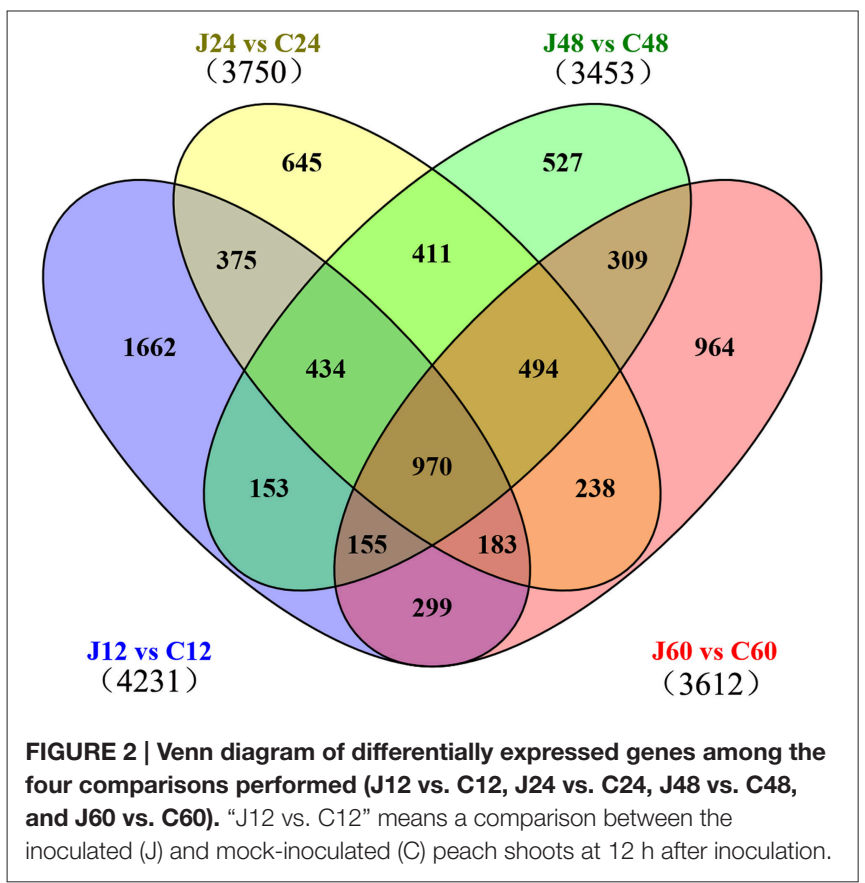

GO terms were assigned to gain an overall understanding of the 920 DEGs identified in the J vs. C analysis. The broad categories for the three major GO functional domains (biological process, cellular component, and molecular function) are shown in Figure 3. The categories "metabolic process," "cellular process," "response to stimulus," "biological regulation," and "pigmentation" were the five representative categories based on the biological process (406 DEGs). The categories "cell," "cell part," "organelle," "organelle part," and "extracellular region," captured most of these genes based on cellular component (416 DEGs), and the categories "catalytic activity," "binding," "transcription regulator activity," and "transporter activity" captured most of these genes based on molecular function (442 DEGs) (Figure 3). Detailed information was obtained through the DAVID online platform (Supplementary Table 5). The terms "phenylpropanoid biosynthetic and metabolic process," "oxidation reduction," "UDP-glucosyltransferase activity," and

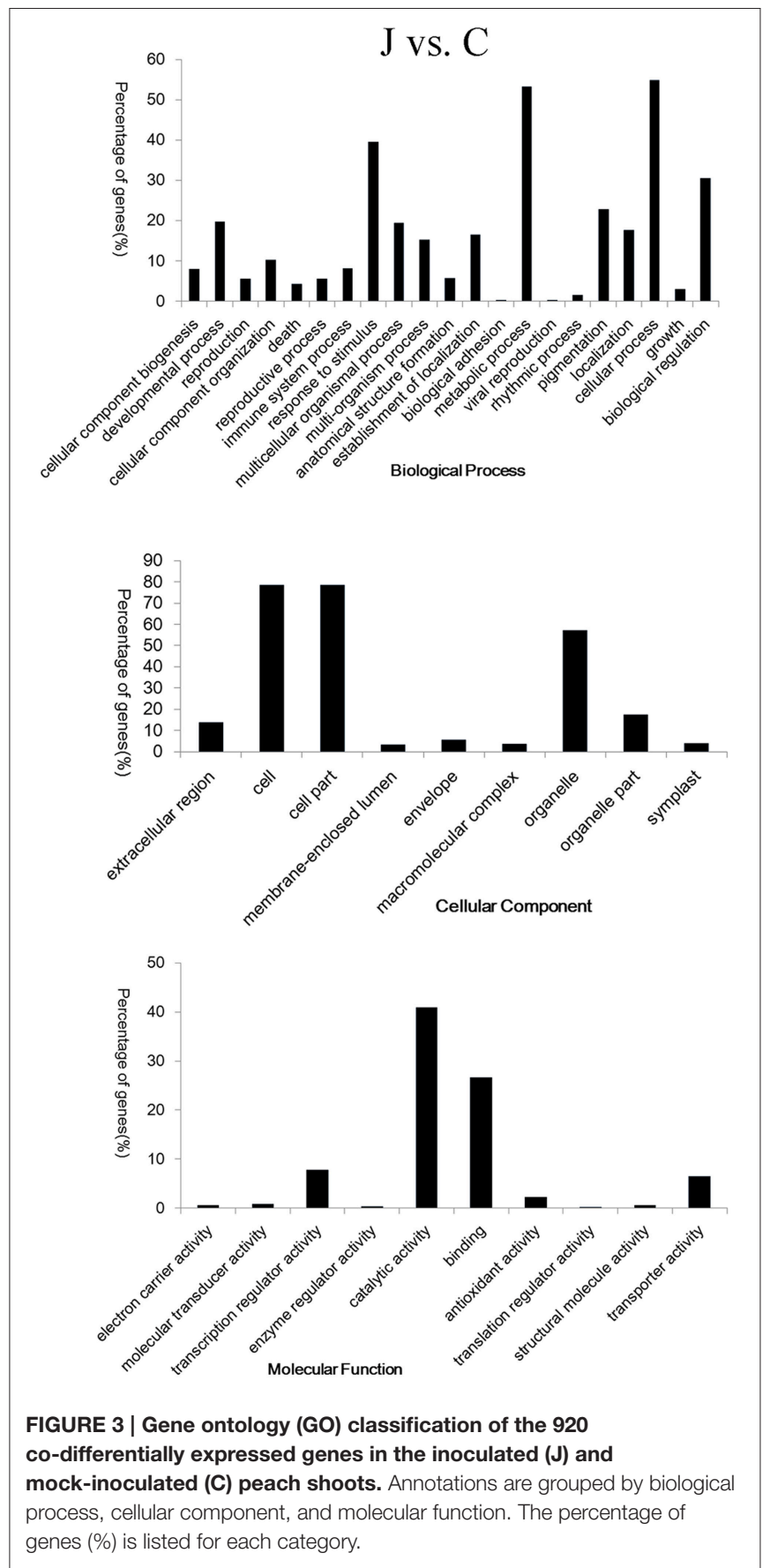

"carbohydrate transport and metabolism or signal transduction mechanisms" were significantly enriched in the upregulated clusters. Photosynthesis was obviously inhibited in the inoculated peach shoots.

\section{Theobromae Infection Significantly Increased the Expression of Genes Involved in Biosynthesis and Metabolism of Phenylpropanoid and the Activity of UDP-Glucosyltransferase}

The qRT-PCR analysis of several genes (Figure 4C) and the heat map diagram of DEGs involved in phenylpropanoid biosynthesis 


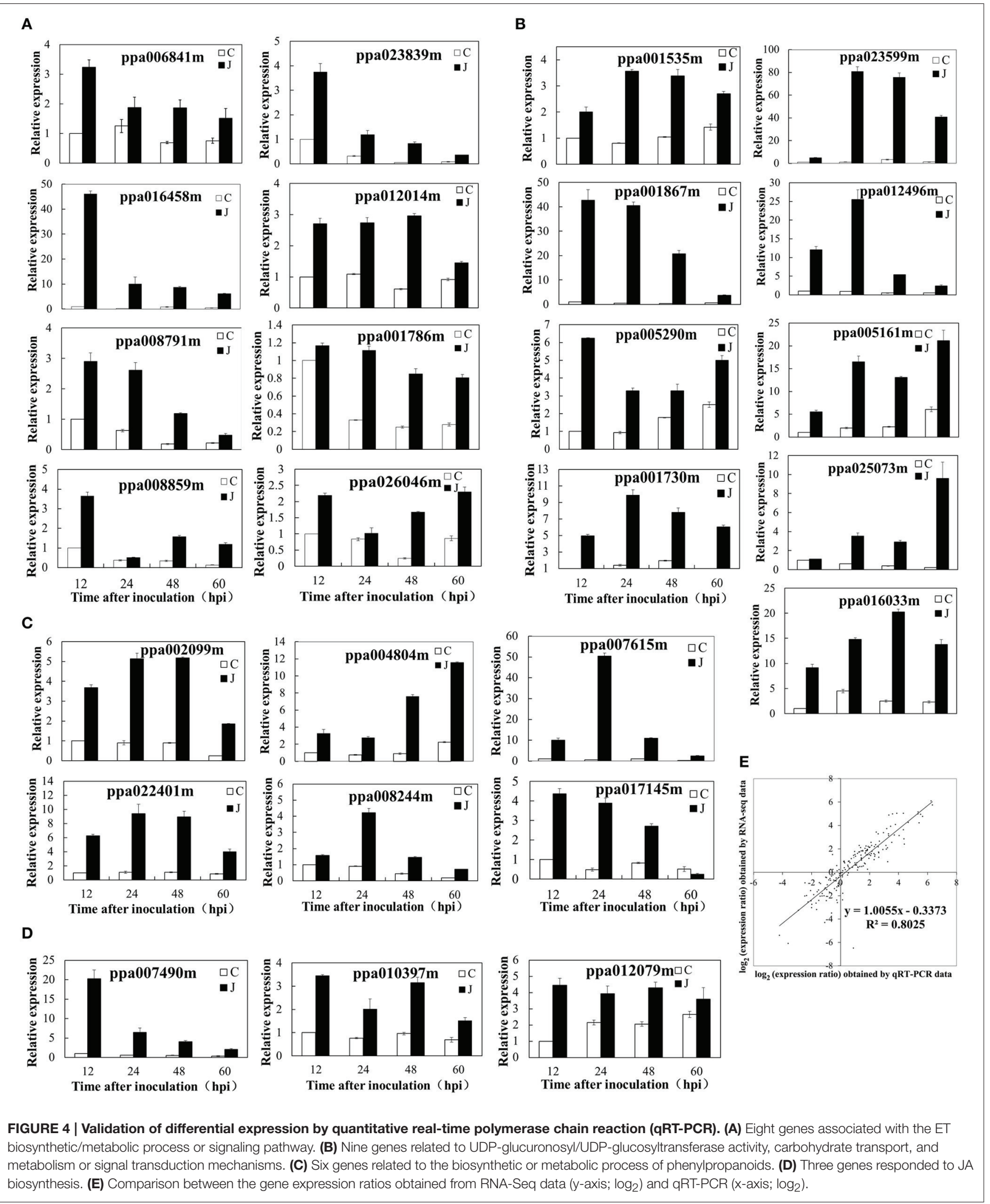


and metabolism (Supplementary Figure 2) also revealed the same result. Higher patterns of expression were exhibited by genes involved in the anthocyanin biosynthetic pathway. These genes include phenylalanine ammonia lyase (ppa002099m), cinnamate-4-hydroxylase (ppa018282m and ppa004544m), 4-coumarate: CoA ligase (ppa003854m and ppa022401m), chalcone synthase (ppa006888m, ppa006899m, ppa008402m, and ppa $023080 \mathrm{~m}$ ), chalcone-flavanone isomerase (ppa011276m), flavanone 3-hydroxylase (ppa007636m), dihydroflavonol 4reductase (ppa008069m), and leucoanthocyanidin dioxygenase (ppa007738m) (Figure 4C; Supplementary Table 8). An overview of genes involved in anthocyanin biosynthetic pathway was presented in Supplementary Figure 3. Genes encoding galactosyltransferase (ppa006755m, ppa022137m, and ppa015950m), UDP-glycosyltransferase and UDPglucosyltransferase were upregulated several to hundreds-fold in the inoculated peach shoots compared with the control shoots (Supplementary Table 9).

\section{Genes Related to Carbohydrate Metabolism are Differentially Expressed during $L$. theobromae Infection}

Cellulose and pectin are the main components of plant cell walls. The expression levels of ppa004653 and ppa004719m (cellulase genes) increased in the inoculated peach shoots compared with those in the control shoots at $24 \mathrm{HAI}$ (2- and 4.6fold, respectively) and 48 HAI (7.5- and 2.8-fold, respectively). Ppa000557m (cellulose synthase 6) was downregulated at 12 HAI. However, several cellulose synthase-like genes were upregulated simultaneously (Supplementary Table 10). The expression of most of the pectin lyase-related genes was promoted within 12$48 \mathrm{HAI}$ in the inoculated peach shoots. Interestingly, pectin methylesterase inhibitor-related genes were almost upregulated as well. At $60 \mathrm{HAI}$, the number of downregulated genes increased. Meanwhile, ppa007271m (gene encoding pectin lyaselike superfamily protein) was significantly upregulated at all HAI periods (Supplementary Table 10).

A comprehensive illustration of carbohydrate metabolism based on the transcriptomic changes during $L$. theobromae infection is presented in Supplementary Figure 4. The expression levels of Sucrose synthase (SS) genes (ppa001535m, ppa017606m, and ppa001135m) were higher in the inoculated peach shoots than in the control shoots. At $60 \mathrm{HAI}$, ppa001535m, and ppa $017606 \mathrm{~m}$ were downregulated in the inoculated peach shoots. Sucrose phosphate synthase (SPS) genes were also upregulated (ppa000622m) or showed this tendency (ppa000636m and ppa000639m) at $60 \mathrm{HAI}$. The expression levels of glucose 6phosphate translocator genes (ppa006608m and ppa006795m) increased in the inoculated peach shoots (Supplementary Figure 5). Ppa007136m (alpha-galactosidase 2) was downregulated in the inoculated peach shoots, indicating that galactose hydrolysis was inhibited. Meanwhile, the expression of ppa008032 (UDPD-glucose 4-epimerase 5) was promoted. UDP-D-glucose 4epimerase (UGE) is the key enzyme in UDP-D-galactose biosynthesis (Seifert et al., 2002; Rösti et al., 2007). The expression levels of ppa008317m (UDP-xylose synthase 4) and ppa001692m (beta-D-xylosidase 4) were also enhanced, especially at 48 HAI. Higher patterns of expression were observed in genes involved in the catabolism of fructose in the inoculated peach shoots relative to the control shoots. These genes include hexokinase (ppa004471m), phosphofructokinase (ppa003994m and ppa004086m), and mannose-6-phosphate isomerase (ppa005846m). However, ppa007744m, ppa025195m, and ppa006746m (encoding aldolase) were downregulated. This result indicates that the further decomposition of fructose-1, 6-bisphosphate was inhibited in the inoculated peach shoots. Fructose-6-bisphosphate can participate in the biosynthesis of D-mannose-6-phosphate (Supplementary Figure 6). In addition, genes related to the degradation of glycosaminoglycan and other glycans were downregulated in the inoculated peach shoots.

\section{Genes Involved in ET and JA Biosynthesis and Signaling were Mainly Upregulated in the Inoculated Peach Shoots}

An overview of genes involved in ET and JA biosynthetic pathway was presented in Supplementary Figure 7. The SAM synthetase (ppa006841m) was overexpressed in the inoculated peach shoots. Higher patterns of expression were also observed (RPKM values) or obtained (qRT-PCR values) in pivotal genes related to the ET biosynthesis. These genes include 1aminocyclopropane-1-carboxylate (ACC) synthase 6 (ppa016458) and ET-forming enzyme (ppa008791m) (Supplementary Figure 8A; Figure 4A). The expression pattern of ppa016458 and ppa008791m was consistent with the variation trend of ET production. Several DEGs encoding ET signaling components have also been identified. The expression levels of ppa023839m and ppa012014m (genes encoding ET response factor) and ppa001786m (ET sensor) determined by qRT-PCR were increased several times to 10 times after $L$. theobromae infection, this result is consistent with the RNA-Seq data (Figure 4A). Other DEGs involved in the ethylene signaling pathway were listed in Supplementary Figure 8A. The protein involved in JA biosynthesis (12-oxophytodienoate reductase 2, ppa007490m) was overexpressed in the inoculated peach shoots. The expression levels (RPKM values) of other genes, such as allene oxide synthase (ppa025045m), allene oxide cyclase 3 (ppa010397m), and allene oxide cyclase 4 (ppa012079m) were higher (two to five-fold) in the inoculated peach shoots than in the control shoots at 12 , 24, and $48 \mathrm{HAI}$, although no difference (ppa010397m and ppa012079m) or lower expression (ppa025045m) was observed at $60 \mathrm{HAI}$. JA-ME is catalyzed by JA carboxyl methyltransferase, this gene (ppa017829m) was upregulated at 12 and $24 \mathrm{HAI}$ and downregulated at 48 and $60 \mathrm{HAI}$ in the inoculated peach shoots (Supplementary Figure 8B). The qRT-PCR results were similar to the RPKM values (Figure 4D).

\section{Verification of Gene Expression Profiles Using qRT-PCR}

At 12, 24, 48, and $60 \mathrm{HAI}$, we collected samples from eight shoots and pooled them for RNA extraction and subsequent RNA-Seq analysis. A one-to-one correspondence exists between $\mathrm{J}$ and $\mathrm{C}$ in this experiment. To confirm the accuracy and reproducibility of the transcriptome analysis 
results, 26 representative genes were selected for real-time qRTPCR validation in a separate experiment. The primers of these genes are shown in Supplementary Table 7, and the The qRTPCR results are shown in Figure 4. The fold change of the gene expression ratios between RNA-Seq and qRT-PCR was analyzed by linear regression. The overall correlation coefficient was 0.8025 , indicating the reliability of the RNA-Seq data (Figure 4E).

\section{DISCUSSION}

\section{Phenylpropanoid Metabolism and Glycosyltransferase Activity of the Inoculated Peach Shoots}

In general, a marked induction of genes is involved in the biosynthesis of phenylpropanoids in plants as a response to pathogens (Shetty et al., 2011; Xu et al., 2011; Kostyn et al., 2012; Muñoz-Bodnar et al., 2014). Phenylpropanoids play important roles in plant resistance to pathogen attacks (Dixon et al., 2002; Korkina, 2007; Naoumkina et al., 2010; Boubakri et al., 2013). In addition, the protective action of phenylpropanoids in plants is assumed to be based on their antioxidant and free radical scavenging properties. Flavonoids are representative substances of phenylpropanoid derivatives in plants (Tahara, 2007). Flavonoids are natural defense compounds in plants against pathogens. Anthocyanins represent one class of flavonoids that are significantly accumulated around the lesions of the inoculated peach shoots, resulting in a red coloration on infected peach shoots (Figure 1A; Li et al., 2014b). As important secondary metabolites, anthocyanins contribute to protect plants against pathogenic attack (Winkel-Shirley, 2001). As a type of abiotic stress, wounds can also induce the flavonoids accumulation. Therefore, a slight red coloration appeared around the wound site of the control shoots (Figure 1A). However, the effect was much less than the stress response induced by $L$. theobromae. Plant UDP-glycosyltransferases and UDPglucosyltransferases can be involved in the modification of phenylpropanoids (Vogt and Jones, 2000). The glycosylated form of these compounds exhibits enhanced solubility, stability, and transport properties ( $\mathrm{Li}$ et al., 2001), and can be stored as preformed defense compounds. The glycosylated defense compounds (e.g., flavonoids) involved during pathogen attacks are activated by deglycosylation (Jasiński et al., 2009). Several genes encoding UGTs play important roles in plant defense against pathogens (Chong et al., 2002; Poppenberger et al., 2003; von Saint Paul et al., 2011). For example, UGT73B3 and UGT73B5 supposedly participate in the regulation of redox status and general detoxification of reactive oxygen species and contribute to the resistance of Arabidopsis to Pseudomonas syringae pv. tomato (Simon et al., 2014).

\section{Carbohydrate Metabolism and Gum Formation of the Inoculated Peach Shoots}

Some pathogens can secrete polygalacturonases and endopolygalacturonases which enable them to penetrate the host plant by degrading the plant cell wall pectin. Botryosphaeria spp. belonging to ascomycetous fungi can degrade lignin and pectin (Alves da Cunha et al., 2003). The pectinase produced by these fungi could degrade the cell wall structures (Srivastava et al., 2013). PMEIs (pectin methylesterase inhibitors) can inhibit pectin methylesterases. Lionetti et al. (2007) reported that PMEIs contributed to the defense of Arabidopsis to B. cinerea. In the present study, the transcript levels of genes encoding PMEIs increased, especially during the early and middle infection periods. The defense response of the peach shoot tissues was stimulated by $L$. theobromae infection. However, some genes encoding pectin lyase-like superfamily protein were also upregulated (Supplementary Table 10). Hence, PMEIs could not completely prevent the breakdown of pectin. Overall, the new biosynthesis of cellulose can be assumed to be accompanied by degradation. The monosaccharide components of peach gum polysaccharides are galactose, arabinose, xylose, mannose, and glucuronic acid (Simas et al., 2008; Simas-Tosin et al., 2009). $\beta$-1,4-linked glucose, xyloglucan, rhamnogalacturonan I, homogalacturonan, rhamnogalacturonan II, and arabinan are representative components of plant cell wall polysaccharides (Vorwerk et al., 2004). A previous study speculated that peach gum arises from the degradation of parenchyma cells around the periderm and vascular cambium (Biggs and Britton, 1988). Recent research has shown that the cell walls were severely degraded in the lesion of inoculated peach shoots ( $\mathrm{Li}$ et al., 2014b). A follow-up study indicated that not only the infection site but also the glycometabolism of tissues around the lesion of the inoculated peach shoots greatly contributes to peach gum formation (Li et al., 2014a). Therefore, the degradation of plant cell walls after inoculation with $L$. theobromae is just one reason for gum formation.

The expression changes of starch metabolism-related genes indicate that amylose decomposition was promoted in the inoculated peach shoots while starch synthesis was inhibited. A previous report indicated that the amyloplast was disappeared during later infection (Li et al., 2014b). SS and SPS are key enzymes in sucrose metabolism (Winter and Huber, 2000; Ruan, 2014). SS has a dual function although it was previously believed to play a major role in sucrose cleavage (Chourey and Nelson, 1979; Geigenberger and Stitt, 1993; Heim et al., 1993). The measurement results of sucrose content (Li et al., 2014a) indicated that sucrose decomposition was promoted before $60 \mathrm{HAI}$ and then biosynthesis reaction was increased. At $60 \mathrm{HAI}$, the peach gum spilled out, and then the increased biosynthesis of sucrose may compensate for the consumed sucrose. Glucose 6-phosphate, provided by the catabolism of sucrose and starch, was an important precursor in the biosynthesis of monosaccharide components of peach gum. The upregulated expression of glucose 6-phosphate translocator will contribute to the biosynthesis of monosaccharide components of peach gum. Our RNA-Seq results revealed that the biosynthesis of UDP-D-galactose, UDP-D-xylose, and D-mannose-6-phosphate was increased in the inoculated peach shoots. Previous study showed that the biosynthesis of UDP-D-arabinose and Larabinose was also enhanced (Li et al., 2014a).

Glycosyltransferases can catalyze the transfer of sugar residue from an activated nucleotide sugar donor to specific acceptor molecules. This process leads to the formation of 
glycosidic bonds that play important roles in the biosyntheses of disaccharides, oligosaccharides, polysaccharides, and glycoconjugates (Campbell et al., 1997; Breton et al., 2006). Common glycosyl donors in plants are UDP-glucose (Jones and Vogt, 2001; Jones et al., 2003), UDP-galactose (Ishikura and Mato, 1993; Miller et al., 1999), UDP-rhamnose (Bar-Peled et al., 1991; Jones et al., 2003), UDP-xylose (Martin et al., 1999), and UDP-glucuronate (Sawada et al., 2005). Interestingly, galactose, arabinose, xylose, mannose, and glucuronic acid are the main monosaccharide components of peach gum polysaccharides (Simas et al., 2008; Simas-Tosin et al., 2009). In the present study, the amount of these glycosyl donors (UDP-glucose, UDPgalactose, UDP-xylose, and UDP-arabinose) was increased. The high expression of genes encoding relevant galactosyltransferases in the inoculated peach shoots may promote the biosynthesis of peach gum polysaccharides.

\section{Involvement of ET and JA in Peach Gummosis Development}

ET is an important plant hormone signal in plant-pathogen interactions (Bleecker and Kende, 2000). ET production of plant tissues can be enhanced by pathogen invasion (Penninckx et al., 1998; Cohn and Martin, 2005). Consistent results were also determined in our study (Figure 1C). That is, ET biosynthesis was promoted, especially at 24 HAI. Sadenosylmethionine (SAM) is a general donor of methyl groups in the transmethylation reactions and is also an important precursor substance of ET synthesis. Tsuchisaka and Theologis (2004) reported that wounding the hypocotyl tissue of Arabidopsis induces the expression of AtACS2, 4, 6, 7, 8, and 11 . In the present study, in addition to wound-treatments, the pathogen challenge aside from wound treatments promoted the expression of ppa016458, as proven in the endogenous production of ET (Figure 1C). Li et al. (2014c) reported that ETH application on peach shoots pre-inoculated with L. theobromae promotes gum formation. ETH treatments accelerated the senescence of peach shoots and rapidly increased the contents of sucrose, glucose, and fructose (Li et al., 2014c), which may promote disease development and facilitate gum formation.

In general, the expression data showed that the genes involved in JA biosynthesis were rapidly induced. A similar result has been observed in Arabidopsis defense against B. cinerea (Birkenbihl et al., 2012; Windram et al., 2012). In Plum pox virus inoculated peach leaves without visible symptoms, JA biosynthesis and signaling genes were upregulated, indicating that JA stimulate plant defense response (Rubio et al., 2015). Interestingly, JA was first isolated from cultures of the fungus L. theobromae (Aldridge et al., 1971). JA biosynthesis in L. theobromae is similar to that in plants (Tsukada et al., 2010). Thus, JA might play a role in the interaction between peach shoots and L. theobromae. Skrzypek et al. (2005b) pointed out that JA-ME substantially reduces the amount of sucrose and reducing sugars in tulips, contributing to gum formation. Li et al. (2015) also speculated that JA-ME treatments cause new synthesis of polysaccharides.

In conclusion, inoculation with $L$. theobromae can induce typical gummosis on current-year peach shoots in vitro. We

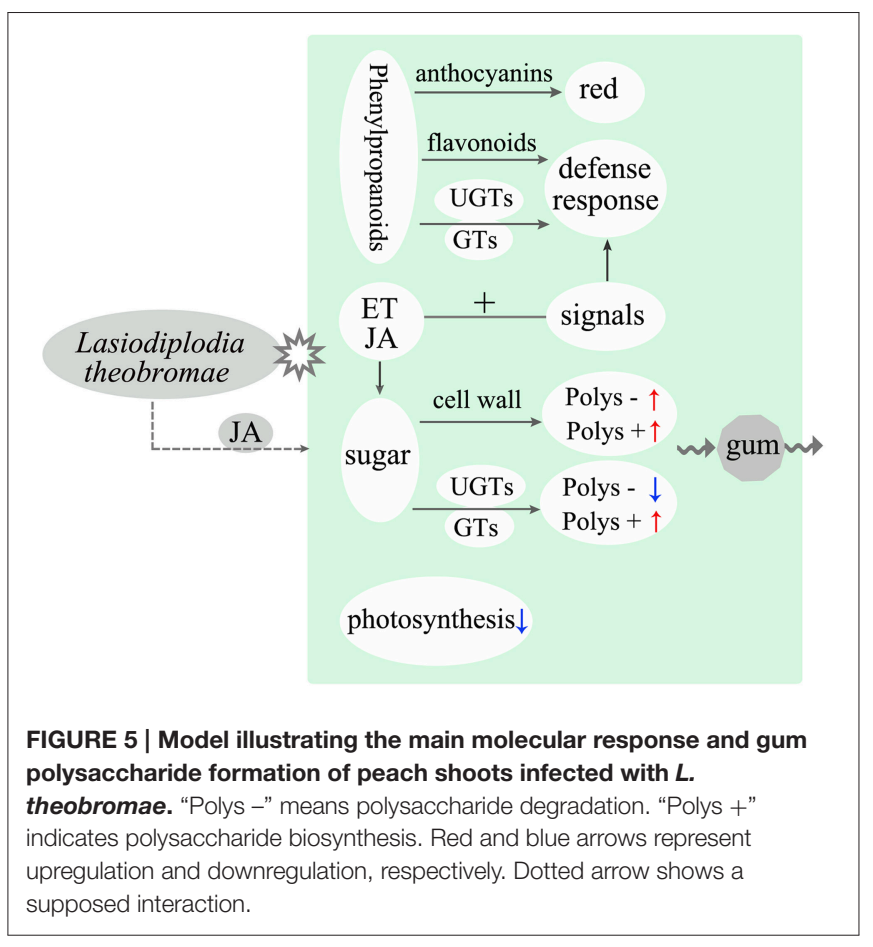

analyzed gene expression changes of the peach shoots at different phases after inoculation through RNA-Seq. The main results of this study are summarized in Figure 5. Plant tissues usually exhibit strong defense responses during $L$. theobromae infection. Genes related to the glycometabolism of the inoculated peach shoots were activated, indicating that polysaccharide biosynthesis was increased. In addition, the expression of genes involved in the degradation of cell walls was promoted, but the degradation of glycosaminoglycan and glycan was inhibited. The above factors might be the main cause of the formation of gum polysaccharides induced by $L$. theobromae. Our study provided insights into the mechanisms of peach gummosis caused by L. theobromae. However, the role of gum in peach tree response to pathogen attacks requires further investigation.

\section{AUTHOR CONTRIBUTIONS}

LG and YW were responsible for generating the RNA-seq data and for the interpretation of the data. LG carried out qRTPCR experiments and measured ethylene content, and drafted the manuscript. GL conceived the study and supervised the research. ZL and JY participated in its design and helped to draft the manuscript. HZ participated in the statistical analyses. All authors approved the final manuscript and approved it for publication.

\section{FUNDING}

This study was supported by the National Natural Science Foundation of China (Grant No. 31471840) and China Agriculture Research System (Grant No. CARS-31-2-4). 


\section{ACKNOWLEDGMENTS}

Thanks the members of my group and ZL for helpful discussions. The raw data of the RNA-Seq has been uploaded to the Sequence Read Archive (SRA). The accession number is SRR3112581.

\section{REFERENCES}

Aldridge, D. C., Galt, S., Giles, D., and Turner, W. B. (1971). Metabolites of Lasiodiplodia theobromae. J. Chem. Soc. C 1623-1627. doi: $10.1039 / \mathrm{j} 39710001623$

Alves da Cunha, M. A., Barbosa, A. M., Giese, E. C., and Dekker, R. F. (2003). The effect of carbohydrate carbon sources on the production of constitutive and inducible laccases by Botryosphaeria sp. J. Basic Microbiol. 43, 385-392. doi: 10.1002/jobm.200310250

Bar-Peled, M., Lewinsohn, E., Fluhr, R., and Gressel, J. (1991). UDPrhamnose: flavanone-7-O-glucoside-2" -O-rhamnosyltransferase. Purification and characterization of an enzyme catalyzing the production of bitter compounds in citrus. J. Biol. Chem. 266, 20953-20959.

Beckman, T. G., Pusey, P. L., and Bertrand, P. F. (2003). Impact of fungal gummosis on peach trees. HortScience 38, 1141-1143.

Biggs, A. R., and Britton, K. O. (1988). Presymptom histopathology of peach trees inoculated with Botryosphaeria obtuse and B. dothidea. Phytopathology 78, 1109-1118. doi: 10.1094/Phyto-78-1109

Birkenbihl, R. P., Diezel, C., and Somssich, I. E. (2012). Arabidopsis WRKY33 is a key transcriptional regulator of hormonal and metabolic responses toward Botrytis cinerea infection. Plant Physiol. 159, 266-285. doi: 10.1104/pp.111.192641

Bleecker, A. B., and Kende, H. (2000). Ethylene: a gaseous signal molecule in plants. Annu. Rev. Cell Dev. Biol. 16, 1-18. doi: 10.1146/annurev.cellbio.16.1.1

Boubakri, H., Poutaraud, A., Wahab, M. A., Clayeux, C., Baltenweck-Guyot, R., Steyer, D., et al. (2013). Thiamine modulates metabolism of the phenylpropanoid pathway leading to enhanced resistance to Plasmopara viticola in grapevine. BMC Plant Biol. 13:31. doi: 10.1186/1471-2229-13-31

Breton, C., Šnajdrová, L., Jeanneau, C., Koča, J., and Imberty, A. (2006). Structures and mechanisms of glycosyltransferases. Glycobiology 16, 29R-37R. doi: $10.1093 /$ glycob/cwj016

Britton, K. O., and Hendrix, F. F. (1982). Three species of Botryosphaeria cause peach tree gummosis in Georgia. Plant Dis. 66, 1120-1121. doi: 10.1094/PD66-1120

Campbell, J. A., Davies, G. J., Bulone, V., and Henrissat, B. (1997). A classification of nucleotide-diphospho-sugar glycosyltransferases based on amino acid sequence similarities. Biochem. J. 326, 929-939. doi: 10.1042/bj3260929u

Chong, J., Baltz, R., Schmitt, C., Beffa, R., Fritig, B., and Saindrenan, P. (2002). Downregulation of a pathogen-responsive tobacco UDP-Glc: phenylpropanoid glucosyltransferase reduces scopoletin glucoside accumulation, enhances oxidative stress, and weakens virus resistance. Plant Cell 14, 1093-1107. doi: 10.1105/tpc.010436

Chourey, P. S., and Nelson, O. E. (1979). Interallelic complementation at the sh locus in maize at the enzyme level. Genetics 91, 317-325.

Cohn, J. R., and Martin, G. B. (2005). Pseudomonas syringae pv. tomato type III effectors AvrPto and AvrPtoB promote ethylene-dependent cell death in tomato. Plant J. 44, 139-154. doi: 10.1111/j.1365-313X.2005.02516.x

Czemmel, S., Galarneau, E. R., Travadon, R., McElrone, A. J., Cramer, G. R., and Baumgartner, K. (2015). Genes expressed in grapevine leaves reveal latent wood infection by the fungal pathogen Neofusicoccum parvum. PLoS ONE 10:e0121828. doi: 10.1371/journal.pone.0121828

de Jonge, R., van Esse, H. P., Maruthachalam, K., Bolton, M. D., Santhanam, P., Saber, M. K., et al. (2012). Tomato immune receptor Ve1 recognizes effector of multiple fungal pathogens uncovered by genome and RNA sequencing. Proc. Natl. Acad. Sci. U.S.A. 109, 5110-5115. doi: 10.1073/pnas.1119623109

de Wild, H. P., Gude, H., and Peppelenbos, H. W. (2002). Carbon dioxide and ethylene interactions in tulip bulbs. Physiol Plant. 114, 320-326. doi: 10.1034/j.1399-3054.2002.1140219.x

\section{SUPPLEMENTARY MATERIAL}

The Supplementary Material for this article can be found online at: http://journal.frontiersin.org/article/10.3389/fphys. 2016.00170
Dixon, R. A., Achnine, L., Kota, P., Liu, C. J., Reddy, M. S., and Wang, L. (2002). The phenylpropanoid pathway and plant defence-a genomics perspective. Mol. Plant Pathol. 5, 371-390. doi: 10.1046/j.1364-3703.2002.00131.x

Geigenberger, P., and Stitt, M. (1993). Sucrose synthase catalyses a readily reversible reaction in vivo in developing potato tubers and other plant tissues. Planta 189, 329-339. doi: 10.1007/BF00194429

Heim, U., Weber, H., Bäumlein, H., and Wobus, U. (1993). A sucrose-synthase gene of Vicia faba L.: expression pattern in developing seeds in relation to starch synthesis and metabolic regulation. Planta 191, 394-401. doi: 10.1007/BF00195698

Ishikura, N., and Mato, M. (1993). Partial purification and some properties of flavonol 3-O-glycosyltransferases from seedlings of Vigna mungo, with special reference to the formation of kaempferol 3-O-galactoside and 3-O-glucoside. Plant Cell Physiol. 34, 329-335.

Jasiński, M., Kachlicki, P., Rodziewicz, P., Figlerowicz, M., and Stobiecki, M. (2009). Changes in the profile of flavonoid accumulation in Medicago truncatula leaves during infection with fungal pathogen Phoma medicaginis. Plant Physiol. Biochem. 47, 847-853. doi: 10.1016/j.plaphy.2009.05.004

Jones, P., Messner, B., Nakajima, J. I., Schäffner, A. R., and Saito, K. (2003). UGT73C6 and UGT78D1, glycosyltransferases involved in flavonol glycoside biosynthesis in Arabidopsis thaliana. J. Biol. Chem. 278, 43910-43918. doi: 10.1074/jbc.M303523200

Jones, P., and Vogt, T. (2001). Glycosyltransferases in secondary plant metabolism: tranquilizers and stimulant controllers. Planta 213, 164-174. doi: 10.1007/s004250000492

Kim, K. H., Kang, Y. J., Kim, D. H., Yoon, M. Y., Moon, J. K., Kim, M. Y., et al. (2011). RNA-Seq analysis of a soybean near-isogenic line carrying bacterial leaf pustule-resistant and-susceptible alleles. DNA Res. 18, 483-497. doi: 10.1093/dnares/dsr033

Korkina, L. G. (2007). Phenylpropanoids as naturally occurring antioxidants: from plant defense to human health. Cell Mol. Biol. 53, 15-25. doi: 10.1170/T772

Kostyn, K., Czemplik, M., Kulma, A., Bortniczuk, M., Skała, J., and Szopa, J. (2012). Genes of phenylpropanoid pathway are activated in early response to Fusarium attack in flax plants. Plant Sci. 190, 103-115. doi: 10.1016/j.plantsci.2012.03.011

Kunjeti, S. H., Evans, T. A., Marsh, A. G., Gregory, N. F., Kunjeti, S., Meyers, B. C., et al. (2012). RNA-Seq reveals infection-related global gene changes in Phytophthora phaseoli, the causal agent of lima bean downymildew. Mol. Plant Pathol. 13, 454-466. doi: 10.1111/j.1364-3703.2011.00761.x

Li, M., Liu, M., Peng, F., and Fang, L. (2015). Influence factors and gene expression patterns during MeJa-induced gummosis in peach. J. Plant Physiol. 182, 49-61. doi: 10.1016/j.jplph.2015.03.019

Li, Y., Baldauf, S., Lim, E. K., and Bowles, D. J. (2001). Phylogenetic analysis of the UDP-glycosyltransferase multigene family of Arabidopsis thaliana. J. Biol. Chem. 276, 4338-4343. doi: 10.1074/jbc.M007447200

Li, Z., Gao, L., Wang, Y. T., Zhu, W., Ye, J. L., and Li, G. H. (2014a). Carbohydrate metabolism changes in Prunus persica gummosis infected with Lasiodiplodia theobromae. Phytopathology 104, 445-452. doi: 10.1094/PHYTO-01-13-0025-R

Li, Z., Wang, Y. T., Gao, L., Wang, F., Ye, J. L., and Li, G. H. (2014b). Biochemical changes and defence responses during the development of peach gummosis caused by Lasiodiplodia theobromae. Eur. J. Plant Pathol. 138, 195-207. doi: 10.1007/s10658-013-0322-4

Li, Z., Zhu, W., Fan, Y. C., Ye, J. L., and Li, G. H. (2014c). Effects of pre- and post-treatment with ethephon on gum formation of peach gummosis caused by Lasiodiplodia theobromae. Plant Pathol. 63, 1306-1315. doi: 10.1111/ppa.12214

Lionetti, V., Raiola, A., Camardella, L., Giovane, A., Obel, N., and Pauly, M., et al. (2007). Overexpression of pectin methylesterase inhibitors in Arabidopsis restricts fungal infection by Botrytis cinerea. Plant Physiol. 143, 1871-1880. doi: $10.1104 /$ pp.106.090803 
Livak, K. J., and Schmittgen, T. D. (2001). Analysis of relative gene expression data using real-time quantitative PCR and the $2^{-\Delta \Delta C T}$ method. Methods 25 , 402-408. doi: 10.1006/meth.2001.1262

Marguerat, S., and Bähler, J. (2010). RNA-seq: from technology to biology. Cell Mol. Life Sci. 67, 569-579. doi: 10.1007/s00018-009-0 $180-6$

Martin, R. C., Mok, M. C., and Mok, D. W. (1999). A gene encoding the cytokinin enzyme zeatinO-xylosyltransferase of Phaseolus vulgaris. Plant Physiol. 120, 553-558. doi: 10.1104/pp.120.2.553

Miller, K. D., Guyon, V., Evans, J. N., Shuttleworth, W. A., and Taylor, L. P. (1999). Purification, cloning, and heterologous expression of a catalytically efficient flavonol 3-O-galactosyltransferase expressed in the male gametophyte of Petunia hybrida. J. Biol. Chem. 274, 34011-34019. doi: 10.1074/jbc.274.48.34011

Miyamoto, K., Kotake, T., Sasamoto, M., Saniewski, M., and Ueda, J. (2010). Gummosis in grape hyacinth (Muscari armeniacum) bulbs: hormonal regulation and chemical composition of gums. J. Plant Res. 123, 363-370. doi: 10.1007/s10265-009-0273-1

Morrison, J. C., Labavitch, J. M., and Greve, L. C. (1987). The role of ethylene in initiating gum duct formation in almond fruit. J. Am. Soc. Hort. Sci. 112, 364-367.

Muniz, C. R., Freire, F. C. O., Viana, F. M. P., Cardoso, J. E., Cooke, P., and Wood, D., et al. (2011). Colonization of cashew plants by Lasiodiplodia theobromae: microscopical features. Micron 42, 419-428. doi: 10.1016/j.micron.2010. 12.003

Muñoz-Bodnar, A., Perez-Quintero, A. L., Gomez-Cano, F., Gil, J., Michelmore, R., Bernal, A., et al. (2014). RNAseq analysis of cassava reveals similar plant responses upon infection with pathogenic and non-pathogenic strains of Xanthomonas axonopodis pv. manihotis. Plant Cell Rep. 33, 1901-1912. doi: 10.1007/s00299-014-1667-7

Naoumkina, M. A., Zhao, Q., Gallego-Giraldo, L., Dai, X., Zhao, P. X., and Dixon, R. A. (2010). Genome-wide analysis of phenylpropanoid defence pathways. Mol. Plant Pathol. 11, 829-846. doi: 10.1111/j.1364-3703.2010.00648.x

Olien, W. C., and Bukovac, M. J. (1982). Ethephon-induced gummosis in sour cherry (Prunus cerasus L.) I. Effect on xylem function and shoot water status. Plant Physiol. 70, 547-555. doi: 10.1104/pp.70.2.547

Penninckx, I. A., Thomma, B. P., Buchala, A., Métraux, J. P., and Broekaert, W. F. (1998). Concomitant activation of jasmonate and ethylene response pathways is required for induction of a plant defensin gene in Arabidopsis. Plant Cell 10, 2103-2113. doi: 10.1105/tpc.10.12.2103

Poppenberger, B., Berthiller, F., Lucyshyn, D., Sieberer, T., Schuhmacher, R., Krska, R., et al. (2003). Detoxification of the Fusarium mycotoxin deoxynivalenol by a UDP-glucosyltransferase from Arabidopsis thaliana. J. Biol. Chem. 278, 47905-47914. doi: 10.1074/jbc.M307552200

Rösti, J., Barton, C. J., Albrecht, S., Dupree, P., Pauly, M., and Findlay, K., et al. (2007). UDP-glucose 4-epimerase isoforms UGE2 and UGE4 cooperate in providing UDP-galactose for cell wall biosynthesis and growth of Arabidopsis thaliana. Plant Cell 19, 1565-1579. doi: 10.1105/tpc.106.049619

Ruan, Y. L. (2014). Sucrose metabolism: gateway to diverse carbon use and sugar signaling. Annu. Rev. Plant Biol. 65, 33-67. doi: 10.1146/annurev-arplant050213-040251

Rubio, M., Rodríguez-Moreno, L., Ballester, A. R., Moura, M. C., Bonghi, C., and Candresse, T., et al. (2015). Analysis of gene expression changes in peach leaves in response to Plum pox virus infection using RNA-Seq. Mol. Plant Pathol. 16, 164-176. doi: 10.1111/mpp.12169

Saniewski, M., Miyamoto, K., and Ueda, J. (1998). Methyl jasmonate induces gums and stimulates anthocyanin accumulation in peach shoots. J. Plant Growth Regul. 17, 121-124. doi: 10.1007/PL00007024

Saniewski, M., Miyamoto, K., and Ueda, J. (2002). "Gum induction by methyl jasmonate in fruits, stems and petioles of Prunus domestica L," in XXVI International Horticultural Congress: Key Processes in the Growth and Cropping of Deciduous Fruit and Nut Trees, Vol. 636 (Toronto, ON), 151-158.

Saniewski, M., Ueda, J., Horbowicz, M., Miyamoto, K., and Puchalski, J. (2001). Gum in apricot (Prunus armeniaca L.) shoots induced by methyl jasmonate. Acta Agrobot. 54, 27-34. doi: 10.5586/aa.2001.020

Sawada, S. Y., Suzuki, H., Ichimaida, F., Yamaguchi, M. A., Iwashita, T., and Fukui, Y., et al. (2005). UDP-glucuronic acid: anthocyanin glucuronosyltransferase from red daisy (Bellis perennis) flowers enzymology and phylogenetics of a novel glucuronosyltransferase involved in flower pigment biosynthesis. J. Biol. Chem. 280, 899-906. doi: 10.1074/jbc.M410537200

Seifert, G. J., Barber, C., Wells, B., Dolan, L., and Roberts, K. (2002). Galactose biosynthesis in Arabidopsis: genetic evidence for substrate channeling from UDP-D-galactose into cell wall polymers. Curr. Biol. 12, 1840-1845. doi: 10.1016/S0960-9822(02)01260-5

Sherif, S., Paliyath, G., and Jayasankar, S. (2012). Molecular characterization of peach $P R$ genes and their induction kinetics in response to bacterial infection and signaling molecules. Plant Cell Rep. 31, 697-711. doi: 10.1007/s00299-0111188-6

Shetty, R., Fretté, X., Jensen, B., Shetty, N. P., Jensen, J. D., and Jørgensen, H. J. L., et al. (2011). Silicon-induced changes in antifungal phenolic acids, flavonoids, and key phenylpropanoid pathway genes during the interaction between miniature roses and the biotrophic pathogen Podosphaera pannosa. Plant Physiol. 157, 2194-2205. doi: 10.1104/pp.111.1 85215

Simas, F. F., Gorin, P. A., Wagner, R., Sassaki, G. L., Bonkerner, A., and Iacomini, M. (2008). Comparison of structure of gum exudate polysaccharides from the trunk and fruit of the peach tree (Prunus persica). Carbohyd. Polym. 71, 218-228. doi: 10.1016/j.carbpol.2007.05.032

Simas-Tosin, F. F., Barraza, R. R., Petkowicz, C. L. O., Silveira, J. L. M., Sassaki, G. L., and Santos, E. M. R., et al. (2010). Rheological and structural characteristics of peach tree gum exudate. Food Hydrocolloid. 24, 486-493. doi: 10.1016/j.foodhyd.2009.12.010

Simas-Tosin, F. F., Wagner, R., Santos, E. M. R., Sassaki, G. L., Gorin, P. A. J., and Iacomini, M. (2009). Polysaccharide of nectarine gum exudate: comparison with that of peach gum. Carbohyd. Polym. 76, 485-487. doi: 10.1016/j.carbpol.2008.11.013

Simon, C., Langlois-Meurinne, M., Didierlaurent, L., Chaouch, S., Bellvert, F., and Massoud, K., et al. (2014). The secondary metabolism glycosyltransferases UGT73B3 and UGT73B5 are components of redox status in resistance of Arabidopsis to Pseudomonas syringae pv. tomato. Plant Cell Environ. 37, 1114-1129. doi: 10.1111/pce.12221

Skrzypek, E., Miyamoto, K., Saniewski, M., and Ueda, J. (2005a). Identification of jasmonic acid and its methyl ester as gum-inducing factors in tulips. J. Plant Res. 118, 27-30. doi: 10.1007/s10265-004-0 190-2

Skrzypek, E., Miyamoto, K., Saniewski, M., and Ueda, J. (2005b). Jasmonates are essential factors inducing gummosis in tulips: mode of action of jasmonates focusing on sugar metabolism. J. Plant Physiol. 162, 495-505. doi: 10.1016/j.jplph.2004.09.007

Socquet-Juglard, D., Kamber, T., Pothier, J. F., Christen, D., Gessler, C., and Duffy, B., et al. (2013). Comparative RNA-seq analysis of early-infected peach leaves by the invasive phytopathogen Xanthomonas arboricola pv. pruni. PLoS ONE 8:e54196. doi: 10.1371/journal.pone.0054196

Srivastava, P., Andersen, P. C., Marois, J. J., Wright, D. L., Srivastava, M., and Harmon, P. F. (2013). Effect of phenolic compounds on growth and ligninolytic enzyme production in Botryosphaeria isolates. Crop Prot. 43, 146-156. doi: 10.1016/j.cropro.2012.09.015

Tahara, S. (2007). A journey of twenty-five years through the ecological biochemistry of flavonoids. Biosci. Biotechnol. Biochem. 71, 1387-1404. doi: 10.1271/bbb.70028

Tsuchisaka, A., and Theologis, A. (2004). Unique and overlapping expression patterns among the Arabidopsis 1-amino-cyclopropane-1-carboxylate synthase gene family members. Plant Physiol. 136, 2982-3000. doi: 10.1104/pp.104.049999

Tsukada, K., Takahashi, K., and Nabeta, K. (2010). Biosynthesis of jasmonic acid in a plant pathogenic fungus, Lasiodiplodia theobromae. Phytochemistry 71, 2019-2023. doi: 10.1016/j.phytochem.2010.09.013

Verde, I., Abbott, A. G., Scalabrin, S., Jung, S., Shu, S., and Marroni, F. (2013). The high-quality draft genome of peach (Prunus persica) identifies unique patterns of genetic diversity, domestication and genome evolution. Nat. Genet. 45, 487-494. doi: 10.1038/ng.2586

Vogt, T., and Jones, P. (2000). Glycosyltransferases in plant natural product synthesis: characterization of a supergene family. Trends Plant Sci. 5, 380-386. doi: 10.1016/S1360-1385(00)01720-9

von Saint Paul, V., Zhang, W., Kanawati, B., Geist, B., Faus-Keßler, T., and SchmittKopplin, P., et al. (2011). The Arabidopsis glucosyltransferase UGT76B1 
conjugates isoleucic acid and modulates plant defense and senescence. Plant Cell 23, 4124-4145. doi: 10.1105/tpc.111.088443

Vorwerk, S., Somerville, S., and Somerville, C. (2004). The role of plant cell wall polysaccharide composition in disease resistance. Trends Plant Sci. 9, 203-209. doi: $10.1016 /$ j.tplants.2004.02.005

Wang, F., Zhao, L. N., Li, G. H., Huang, J. B., and Hsiang, T. (2011). Identification and Characterization of Botryosphaeria spp. Causing Gummosis of Peach Trees in Hubei Province, Central China. Plant Dis. 95, 1378-1384. doi: 10.1094/PDIS12-10-0893

Wang, Z., Gerstein, M., and Snyder, M. (2009). RNA-Seq: a revolutionary tool for transcriptomics. Nat. Rev. Genet. 10, 57-63. doi: 10.1038/nr g2484

Weaver, D. J. (1974). A gummosis disease of peach trees caused by Botryosphaeria dothidea. Phytopathology 64, 1429-1432. doi: 10.1094/Phyto-6 4-1429

Windram, O., Madhou, P., McHattie, S., Hill, C., Hickman, R., and Cooke, E., et al. (2012). Arabidopsis defense against Botrytis cinerea: chronology and regulation deciphered by high-resolution temporal transcriptomic analysis. Plant Cell 24, 3530-3557. doi: $10.1105 /$ tpc.112.102046

Winkel-Shirley, B. (2001). Flavonoid biosynthesis. A colorful model for genetics, biochemistry, cell biology, and biotechnology. Plant Physiol. 126, 485-493. doi: 10.1104/pp.126.2.485
Winter, H., and Huber, S. C. (2000). Regulation of sucrose metabolism in higher plants: localization and regulation of activity of key enzymes. Crit. Rev. Plant Sci. 19, 31-67. doi: 10.1016/S0735-2689(01)80002-2

Xu, L., Zhu, L. F., Tu, L. L., Liu, L. L., Yuan, D. J., and Jin, L., et al. (2011). Lignin metabolism has a central role in the resistance of cotton to the wilt fungus Verticillium dahliae as revealed by RNA-Seq-dependent transcriptional analysis and histochemistry. J. Exp. Bot. 62, 5607-5621. doi: 10.1093/jxb/err245

Zhang, Y. Q., Pei, X. W., Zhang, C., Lu, Z. F., Wang, Z. X., and Jia, S. R., et al. (2012). De novo foliar transcriptome of Chenopodium amaranticolor and analysis of its gene expression during virus-induced hypersensitive response. PLOS ONE 7:e45953. doi: 10.1371/journal.pone.0045953

Conflict of Interest Statement: The authors declare that the research was conducted in the absence of any commercial or financial relationships that could be construed as a potential conflict of interest.

Copyright $\odot 2016$ Gao, Wang, Li, Zhang, Ye and Li. This is an open-access article distributed under the terms of the Creative Commons Attribution License (CC BY). The use, distribution or reproduction in other forums is permitted, provided the original author(s) or licensor are credited and that the original publication in this journal is cited, in accordance with accepted academic practice. No use, distribution or reproduction is permitted which does not comply with these terms. 